\title{
Role of employee motivation on employee's commitment in the context of banking sector of D.G.KHAN, Pakistan
}

\author{
Nadeem Iqbal ${ }^{1}$, Naveed Ahmad ${ }^{2}$, Muhammad Majid ${ }^{3}$, Muhammad Nadeem ${ }^{4}$, Komal Javed $^{5}$, \\ Afsheen Zahra ${ }^{5}$, Muhammad Ateeq ${ }^{5}$ \\ ${ }^{1}$ Faculty of Management Sciences, Baha Uddin Zakariya University Multan, Pakistan \\ ${ }^{2}$ Faculty of Management sciences, Indus international institute, D. G. Khan, Pakistan \\ ${ }^{3}$ Department of Business Administration, National University of Modern Languages (NUML), Pakistan \\ ${ }^{4}$ Department of Business Administration, National University of Modern Languages (NUML), Pakistan \\ ${ }^{5}$ Baha uddin Zakariya university, Pakistan

\section{Email address:} \\ drnadeemiqbal1@gmail.com
}

\section{To cite this article:}

Nadeem Iqbal, Naveed Ahmad, Muhammad Majid, Muhammad Nadeem, Komal Javed, Afsheen Zahra, Muhammad Ateeq. Role of Employee Motivation on Employee's Commitment in the Context of Banking Sector of D.G.KHAN, Pakistan. Journal of Human Resource Management. Vol. 1, No. 1, 2013, pp. 1-8. doi: 10.11648/j.jhrm.20130101.11

\begin{abstract}
Motivation of the employee's is the major issue in the today's organizations. Our study focuses on to find out the relationship of motivation and employee's commitment. Two number of hypothesis are surveyed in our study also we have two numbers of research objectives. The statistical population in this research covers employees of "Banking Sector" of D.G.Khan out of whom 45 employees are selected randomly as sample group. Data was collected by standard questionnaire. For data analysis, correlation coefficient was used through "ANOVA and IBM SPSS". There are the two determinants of Motivation which are job involvement and Incentives. Results showed Positive relationship between Job Involvement and employee's commitment and also there is the Positive relationship between Incentives and employee commitment. Divisional banks can use the motivation as their key element to improve the performance of their employees.
\end{abstract}

Keywords: Motivation, Employee's Commitment, Job Involvement, Incentives

\section{Introduction}

In this era of globalization and competition motivation is considered to be the key factors for success and excellence of organizations. Organizations are facing many fluctuations and pressures in today's world in order to carry on organizational life. They have taken employee commitment into their development processes and with understanding the effective changes that will give them desired results.

Mowday, Porter, steer (1982) get "Employee Commitment as affection and trustworthiness". Beckeri, Randal, and Riegel (1995) defined the employee commitment in the three dimensions: the $1^{\text {st }}$ one is a strong goal to remain a member of a particular organization; the $2^{\text {nd }}$ one is a willingness to utilize high levels of struggles on behalf of the organization; and the $3^{\text {rd }}$ one is a describe belief in and appropriateness of the values and goals organization. Pinar Güngör (2011) says "Motivation is the competency or capability of a person to change behavior". Motivation is a driven force that leads and directed a person toward some specific goals."Work motivation is set of active forces that initiates both within as well as outside an individual's being, to starts work-related behavior, and to determine its form, direction, intensity and duration" (Pinder, 1998).Employee commitment can improve the performance of an organization but some time it is not delivering the benefit in many cases like when organization not given them the incentives and involve them in their jobs. That gap is fulfilled when organization characterize employee work-place climate and trust between colleagues (Care 2007).Meaning of job involvement, motivation and employee commitment is clear. The consequences of work will be affected when employees are motivated and committed (Lawler, 1986). The more motivated employees are typically placed additional exertions because they are more committed and involve in their jobs (Blau, 1986; Blau, \&Boal, 1987). 


\subsection{Research Objectives}

The objective of this research is to develop a model in between Motivation and Employee Commitment.

These are included:

1. To see the impact of job involvement on employee commitment.

2. To see the impact of incentives on employee commitment.

\subsection{Research Questions}

There are two types of research objectives including

Q1. What is the relationship exists between job involvement and employee commitment?

Q2. What is the relationship exists between incentives and employee commitment?

Employees 'motivation raises the satisfaction of the employees and involves them in their jobs, by that the employees become creative and they can improve the performance of their organization (Kamery, 2004; Nelson, 1996; Ekerman, 2006).

This research provide the clear appreciation to the executives of today's organizations that how to motivate the employees of their organization. They motivate their employees that they can easily achieve the goals and objectives of their organization by that the profitability of the organization increases and organization get the maximum market share.

\section{Literature Review}

\subsection{Motivation}

There are two motivating factors of job which were observed by some researchers (Mottaz, 1985; Wong et al., 1999; Mahaney and Lederer, 2006; Bakay and Huang, 2010), these two variables are, separate as an intrinsic variable and extrinsic variable. Wong et al. (1999), says about the intrinsic variables contains feelings of involvement, interesting work, career development and promotion. And the extrinsic variables, they are job security, respectable salary, thoughtful discipline, and good working conditions (Curtis et al., 2009). Deci (1975) explains intrinsic motivation as action or behaviors that "a person involves in to feel capable and self-determining". And Extrinsic motivation is defined by (Mahaney and Lederer, 2006) according to them extrinsic motivation tools are includes such factors which are pay, job security, promotions, private office space and the social climate. Furthermore they include competitive salaries, pay raises, merit bonuses and such indirect forms of payment as vacation and compensatory time off and external to the job itself.

Determinants of Motivation Based on Literature:

The meaning of motivation for employees is understandable. That is only the factor in which employees achieve the goals and objectives of their organization.
(Berman, Bowman, West, \& Wart, 2010).Employees' motivation raises the satisfaction of the employees and involves them in their jobs, by that the employees become creative and they can improve the performance of their organization (Kamery, 2004; Nelson, 1996; Ekerman, 2006). So,

There are two determinants of motivation:

1) Job Involvement

2) Incentive

\subsection{Job Involvement}

In this case an individual anxious involved his or her self to achieve a mission related problems; these are might possible individual physical characteristics any of the workers. Reitz and Jewell (1979) believed that the meaning of work in person's predictable or day-to-day existence is called as job involvement. That shows if an individual contributes his attention towards his or her work efficiently then that person is become trustworthy with his or her association.

\subsection{Incentives}

Additional amount other than the work which a worker does is known as incentives. Somewhat which is established as the fright of punishment, the expectation of remuneration and to influence accomplishment stimulates exertion. Koch (1998) approves that every employee needs no-discrimination, reasonable benefit, she also explain that they need to be accepted for their assistances. She debates that commitment of the employees can no extended be bought -- if it ever might

\subsection{Incentive System}

Different banks are offered different incentives systems which are: 1)Performance system definite objectives are allocating in the beginning of year checked periodical when employees are expressed where they stand and in what way they can develop themselves. If the employees meet the objective they are given amplification for the act like 20\% of base pay.2) Career planning is a fundamental incentive, for this determination different options, workshops are planned and the bank also stand for educational expenditures of employees if they have lack of education. When workers get more education they are encouraged according to their innovative knowledge. So upgrades are not the portion of annual broadconference.3) Job rotation is a different incentive system offered at banks. It not only rises the talent and awareness of the employees but also not to make them lazy. 4) Certain insurance programmes are also providing to employees like lifetime insurance, health insurance. Loans on informal payments are providing to employees for the car, home etc.5) The bank offers three regular bonuses, one is annual bonus that differs permitting to the productivity of the bank and other two bonuses are specified on first of Ramadan and on EID-UL-ADHA. 
These two bonuses are of stableaggregate.6)Certain rewards are agreed on the performance of supervise these are economic as well as non-monetary payments like diplomas, cell phones, small donations, feast with officers etc.

The implications of Maslow's Hierarchy of needs:

An incentive program should be directed at a person's psychological income needs. Money can be inexplicable because it may drive to financial needs. Select prizes that are exceptional and applicable to the sponsor, so they may increase physical evidence of their success and achieve their requirement for recognition, acknowledgement and individual or self-esteem.

\subsection{Employee's Commitment}

Employee's commitment is an important tool for improving the performance of the organizations. Researchers conducted on commitment have shown that employees with higher organizational commitment involve in organizational citizen behavior (OCB) and the results to enhanced performance and higher work motivation that are beneficial for the organization (Chang et al., 2007). So employees' efficiency is largely related to their motivation levels and a higher level of organizational commitment. Mowdayet al. clear the definition of organizational commitment as that is a strong faith or belief in an organization's goals, and values, a willingness to utilize substantial effort on behalf of an organization and a member of that organization. Demographic factors which are age, gender, marital status, education level and work experience must found to be considerably related to organizational commitment (B. Mannheim et al). Organization commitment has been discussed in the private, public and non-profit sector also internationally. According to the early research organizational commitment have two popular approaches which are commitment-related attitudes and commitment-related behaviours (Angle and Perry, 1981; Mowday et al (1979; Hall, 1977).Employee's commitment is a Psychological attachment of an employee with the organization that depends on the degree of employee's motivation, involvement, loyalty, and trust in the values and norms of the organization.

\subsection{Hypotheses}

There are two types of hypotheses in this study, Included:

Hypotheses1: There is the Positive relationship exist between job involvement and employee commitment.

Hypotheses2: There is the Positive relationship exist between incentives and employee commitment.

\subsection{Conceptual Framework}

$\begin{array}{cc}\text { Independent } & \text { Dependent } \\ \text { Variable } & \text { Variable }\end{array}$

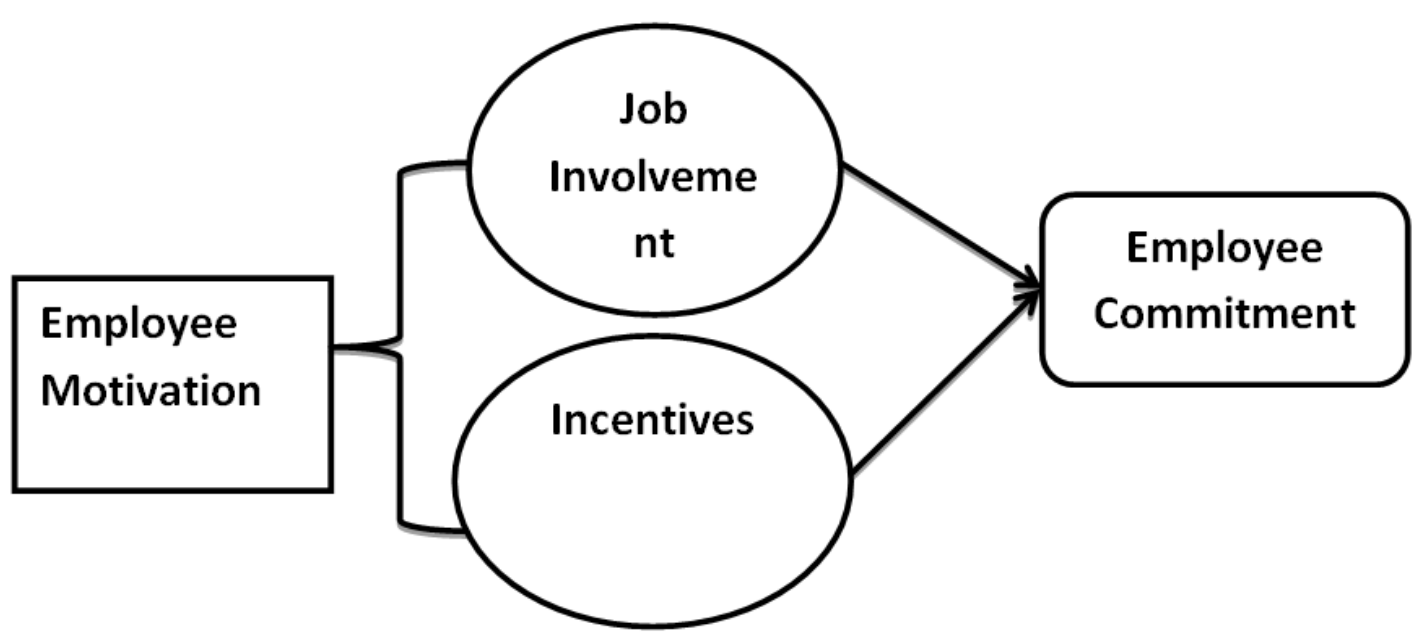

\section{Methodology}

In this study firstly we have describe employee motivation have the direct link with the employee commitment in literature.

\subsection{Research Design}

Different researchers explain or describe certain issues about important variables of the study by descriptive research design. Purpose according to Ezeani, (1998) is to collect detailed and factual information that describes an existing phenomenon. We adopt the descriptive research design where the population is banking sector of Dera Ghazi Khan. The design was suitable because the key concentration was to search the link and define how the elements that maintained. 


\subsection{Target Population}

The population which we target in this study was the employed persons in the banking industry of Dera Ghazi Khan in Pakistan. The population representative was as brief in the table 1 to table 3 .

Table 1. Frequency What is your gender?

\begin{tabular}{ccccc}
\hline Valid & Frequency & Percent Valid & Commutative & Y Percent \\
\hline 1.00 & 25 & 55.6 & 55.6 & 55.6 \\
2.00 & 20 & 44.4 & 44.4 & 100.0 \\
Total & 45 & 100.0 & 100.0 & \\
\hline
\end{tabular}

Table 2. What is your age?

\begin{tabular}{ccccc}
\hline Valid & Frequency & Percent & $\begin{array}{c}\text { Valid } \\
\text { Percent }\end{array}$ & $\begin{array}{c}\text { Cumulative } \\
\text { Percent }\end{array}$ \\
\hline 1.00 & 16 & 35.6 & 35.6 & 35.6 \\
2.00 & 17 & 37.8 & 37.8 & 73.3 \\
3.00 & 12 & 26.7 & 26.7 & 100.0 \\
Total & 45 & 100.0 & 100.0 & \\
\hline
\end{tabular}

Table 3. What is your education?

\begin{tabular}{ccccc}
\hline Valid & Frequency & Percent & $\begin{array}{c}\text { Valid } \\
\text { Percent }\end{array}$ & $\begin{array}{c}\text { Cumulative } \\
\text { Percent }\end{array}$ \\
\hline 1.00 & 5 & 11.1 & 11.1 & 11.1 \\
2.00 & 30 & 66.7 & 66.7 & 77.8 \\
3.00 & 10 & 22.2 & 22.2 & 100.0 \\
Total & 45 & 100.0 & 100.0 & \\
\hline
\end{tabular}

Table 4. Descriptive Statistics

\begin{tabular}{cccc}
\hline & Mean & Std. Deviation & N \\
\hline JB & 1.8148 & .20515 & 45 \\
I & 1.7578 & .14379 & 45 \\
EC & 1.7889 & .28955 & 45 \\
\hline
\end{tabular}

\subsection{Sampling Design}

In the above mention population we were expending simple random sampling which gives every item in the population an equal chance of to be selected. For this survey, 45 respondents were selected representative a population. This was so as further most of the staff associates were conscious for the information necessary for the research, low-cost and cost effective way by the limited time the study was to be completed as table 4 .

\subsection{Data Collection}

The feedback form is the key information gathering tool. The queries were planned to gather quantitative data. Data has been together by means of a standard questionnaire that contains general questions (gender, age and level of education). By using Likert scale fifth continuum from $1=$ strongly agree to $5=$ strongly disagree in this questionnaire.

\subsection{Data Analysis}

Data analysis include the essential features and relationships of variables in order to generalize from the determine patterns of behaviour and specific outcomes. A descriptive analysis was employed. Data was collected according to frequency distribution to point out variable values and number of occurrences in terms of frequency. Frequency distribution table was informative to précis the data from respondents.

In order to study the validity of the questionnaire we evaluate the hypotheses, we used correlation analysis and regression analysis by applying of SPSS software has been used to analyse statistical data of the study. The face validity of the questionnaire has been confirmed through opinions. Determining of reliability of the questionnaire has been done through a sample with the volume of 45 individuals of the members of 15 banks in Dera Ghazi khan.

\subsection{Findings}

The purpose of this study is to find out the relations between Motivation and employees' Commitment. The obtained results show a direct relation between Motivation and employee's Commitment. By considering these results, we are going to study each one of the hypotheses.

Hypotheses 1: Correlation results presented in indicate that there was significant positive relationship between job involvement and employee's commitment (sig=.000 $\mathrm{r}=.524)$. $\mathrm{R}$ is the multiple correlation coefficients, between the observed and predicted values job involvement of the dependent variable employee commitment. In the range of 0 to $1 \mathrm{r}$ value is significant.

Hypotheses2:

Correlation results presented in indicate that there was significant positive relationship between incentive and employee's commitment ( $\mathrm{sig}=.000 \mathrm{r}=.736) . \mathrm{R}$ is the multiple correlation coefficients, between the observed and predicted values incentive of the dependent variable employee commitment. In the range of 0 to $1 \mathrm{r}$ value is significant.

\section{Discussions}

The research emphases on the relationship between Motivation and employee's Commitment. The attained results show the direct relation exist between Motivation and employee's Commitment and motivation have two determinants job involvement and incentives both shows the direct and positive correlation with one another. If motivation is successfully used in the banks of Dera Ghazi Khan, the employees would be able to know how well they are motivated and what is expected to them in future in terms of their work motivation and effort

\section{Conclusion}

The basic purpose of a motivation of employees is to involve the employees in their job and give them incentives as they become committed with their organization. The purpose is only to improve the employee performance that will leads towards the organization success. Employee motivation must be deeply observed the people and 
recognize that employees are the most important resource. The findings of this study conducted from the 45 employees of banking sector in Dera Ghazi Khan seem to suggest that banks interested in improving their motivation level through job involvement and giving incentives to the employees of the organization. Banks should seek to enhance the employee's motivation so that they become satisfied. The study can provide advantage other divisions of Pakistan's banks (both public and private) for improving their employee's motivation level through incentives and job involvement. Our study will also be useful for the HR practitioners because motivation and employee's commitment are the functions of HR management. The citizens of Pakistan who are interested to implement the motivation this study can also be beneficial for them. Finally, the study will help other researchers who might want to start research in the area of employee's commitment and motivation.

\section{Future Research Directions}

There are few drawbacks of our study first there is no previous study exist about motivation in the area of Dera Ghazi Khan many researchers have transference about it in foreign periods and different well-known cities of Pakistan. Second the duration of our study and data resources are very few if we have proper resources and time, we can do our study much deeply and can analyses each and every aspect that distress the motivation of employees toward better commitment of employees. Finally, this discovery is beginning and as the analysers goes profounder; they may alter and become more aware. The study is still in progress and the research will continue to review the findings. Our research time duration is 4months and simple random method is use for data gathering. The researcher can also take other variables like empowerment, leadership styles, job design and managerial standards to improve the employee's performance.

\section{Appendix: (A): Tables of SPSS}

Table 5.Correlations

\begin{tabular}{|c|c|c|c|c|}
\hline & & JB & I & EC \\
\hline \multirow{3}{*}{ JB } & Pearson Correlation & 1 & $.525 * *$ & $.524 * *$ \\
\hline & Sig. (2-tailed) & & .000 & .000 \\
\hline & $\mathrm{N}$ & 45 & 45 & 45 \\
\hline \multirow{3}{*}{ I } & Pearson Correlation & $.525 * *$ & 1 & $.736 * *$ \\
\hline & Sig. (2-tailed) & & .000 & .000 \\
\hline & $\mathrm{N}$ & 45 & 45 & 45 \\
\hline \multirow[b]{2}{*}{$\mathrm{EC}$} & Pearson Correlation & $.524 * *$ & $.736^{* *}$ & 1 \\
\hline & $\begin{array}{c}\text { Sig. (2-tailed) } \\
\mathrm{N}\end{array}$ & $\begin{array}{c}.000 \\
45\end{array}$ & $\begin{array}{l}.000 \\
45\end{array}$ & 45 \\
\hline
\end{tabular}

$\mathrm{H} 1$ : There is a positive $\mathrm{r} / \mathrm{s} \mathrm{b} / \mathrm{w}$ job involvement and employee commitment.

Table 6. Model Summary

\begin{tabular}{|c|c|c|c|c|c|c|c|c|c|}
\hline \multirow[b]{2}{*}{ Mode } & \multirow[b]{2}{*}{ R I } & \multirow[b]{2}{*}{ R Square } & \multirow[b]{2}{*}{$\begin{array}{l}\text { Adjusted R } \\
\text { Square }\end{array}$} & \multirow{2}{*}{$\begin{array}{c}\text { Std. Error of } \\
\text { the } \\
\text { Estimates }\end{array}$} & \multicolumn{5}{|c|}{ Change Statistics } \\
\hline & & & & & R Square & F Change & $\begin{array}{c}\text { df1 } \\
\text { Change }\end{array}$ & $\begin{array}{c}\text { df2 } \\
\text { Change }\end{array}$ & Sig. F \\
\hline 1 & $.524^{\mathrm{a}}$ & .275 & .258 & .24941 & .275 & 16.302 & 1 & 43 & .000 \\
\hline
\end{tabular}

a. Predictors: (Constant), JB

Table 7. ANOVA

\begin{tabular}{ccccc}
\hline Model & Sum of Squares & df Mean Square & F & Sig. Regression \\
\hline 1.014 & 1 & 1.014 & 16.302 & $.000^{\mathrm{b}}$ \\
1 & Residual & 2.675 & 43 & .062 \\
Total & & 3.689 & 44 \\
\hline
\end{tabular}

a. Dependent Variable: EC, b. Predictors: (Constant), JB

$\mathrm{H} 2$ : There is a positive $\mathrm{r} / \mathrm{s} \mathrm{b} / \mathrm{w}$ incentives and employee commitment.

Table 8. Model Summary

\begin{tabular}{|c|c|c|c|c|c|c|c|c|c|}
\hline \multirow[b]{2}{*}{ Mode } & \multirow[b]{2}{*}{ R I } & \multirow[b]{2}{*}{ R Square } & \multirow[b]{2}{*}{$\begin{array}{l}\text { Adjusted R } \\
\text { Square }\end{array}$} & \multirow{2}{*}{$\begin{array}{c}\begin{array}{c}\text { Std. Error of } \\
\text { the } \\
\text { Estimates }\end{array} \\
\end{array}$} & \multicolumn{5}{|c|}{ Change Statistics } \\
\hline & & & & & R Square & F Change & $\begin{array}{c}\text { df1 } \\
\text { Change }\end{array}$ & $\begin{array}{c}\text { df2 } \\
\text { Change }\end{array}$ & Sig. F \\
\hline 1 & $.73^{\mathrm{a}}$ & .542 & .532 & .19819 & .542 & 50.918 & 1 & 43 & .000 \\
\hline
\end{tabular}

a. Predictors: (Constant), I

Table 9. ANOVA

\begin{tabular}{ccccc}
\hline & Model & Sum of Squares & df Mean Square & F \\
\hline Regression & 2.000 & 1 & 2.000 & 50.918 \\
1 Residual & 1.689 & 43 & .39 & $.000^{\mathrm{b}}$ \\
Total & 3.689 & 44 & & \\
\hline
\end{tabular}

a. Dependent Variable: EC, b. Predictor: (Constant), I 
Table 10. Coefficients

\begin{tabular}{ccccccc}
\hline Model & Unstandardized Coefficients & Standardized & t Sig. & \multicolumn{2}{c}{ Coefficients } \\
\hline & & & & B & Std. Error & Beta \\
1 & (Constant) & & -.817 & .366 & -2.230 & .031 \\
I & & 1.483 & .208 & .736 & 7.136 & .000 \\
\hline
\end{tabular}

a. endent Variable: EC

Table 11: Coefficients

\begin{tabular}{ccccccc}
\hline Model & Unstandardized Coefficients & Standardized & t Sig. & \multicolumn{2}{c}{ Coefficients } \\
\hline & & & & B & Std. Error & Beta \\
1 & (Constant) & & .446 & .335 & 1.332 & .190 \\
JB & .740 & .183 & .524 & 4.038 & .000 \\
\hline
\end{tabular}

a. Dependent Variable: EC

\section{Appendix (B):}

\section{General Information}

(1) Gender:

(2) Age group:

(3) Level of education:

(4) Job designation:
Male: $\square \quad$ Female: $\square$

21-25: $\square \quad$ 26-30: $\square \quad$ above $30: \square$

Under-Graduate: $\square \quad$ Graduate: $\square$ Post-Graduate:

\section{The response scale for the questions is as below:} 1= Strongly Agree, $2=$ Agree, $3=$ Uncertain, $4=$ Disagree, $5=$ Strongly Disagree

1. Motivation helps to boost the importance of the job?

2. Work timetable is valuable in job involvement?

3. Job involvement reduces the time overriding into the job?

4. New technology introducing helps the job involvement?

5. Is the positive approach is effective in the job involvement?

6. Are workshop \& training programs helps to improve the job involvement?

7. Is cafeteria is nearer to the work spot?

8. Vacation holiday enhance the job involvement into the worker?

9. Is your superior provides the unique ideas to improve the job Involvement?

10. Both monetary \&non-monetary incentives are important for the worker?

11. For employees motivation money is enough?

12. Clear lane for career advancement leads to enhanced output?

13.Training and development programs enhance performance of the employee?

14.Are workers lose motivation due to less value for incentives?

15. There is a regular and fair system of plunder?

16. Handing over authority in one's work is an key reward?

17. Worker shows more interest at work if they are sure of incentives being delivered as announced? 


\begin{tabular}{|c|c|c|c|c|c|}
\hline 18. There is a regular and fair system of rewards? & 1 & 2 & 3 & 4 & 5 \\
\hline $\begin{array}{l}\text { 19.Do rotation of employees in various departments is an important motivation means to } \\
\text { improve performance? }\end{array}$ & 1 & 2 & 3 & 4 & 5 \\
\hline $\begin{array}{l}\text { 20. The association offers friendly strategies/flexible working activities to help you } \\
\text { accomplish non-work obligations }\end{array}$ & 1 & 2 & 3 & 4 & 5 \\
\hline 21. It would be problematic for you to find a new job you are satisfied with? & 1 & 2 & 3 & 4 & 5 \\
\hline 22. Do you have a high level of independence with your working schedules? & 1 & 2 & 3 & 4 & 5 \\
\hline 23. Do you have recognized with the goals of the association? & 1 & 2 & 3 & 4 & 5 \\
\hline $\begin{array}{l}\text { 24. Are you continue to do work for the association when you have feared the financial } \\
\text { significances of leaving? }\end{array}$ & 1 & 2 & 3 & 4 & 5 \\
\hline $\begin{array}{l}\text { 25. Are you continued to do work for the association when you have fear the loss of social } \\
\text { draws if you leave? }\end{array}$ & 1 & 2 & 3 & 4 & 5 \\
\hline
\end{tabular}

\section{References}

[1] Becker, T. E.; Randal, D.M, \&Riegel, C.D. (1995). "The multidimensional view of commitment and theory of reasoned action: A comparative evaluation:"Journal of Management, 21(4): 617-638.

[2] R. T. Mowday, L. W. P. a. R. M. S. (1982). "EmployeeOrganization Linkages: The Psychology of Commitment, Absenteeism and Turnover," " Academic Press,Inc., New York

[3] CC, P. (1998). "Work Motivation in Organizational Behavior." Upper Saddle River, NJ: Prentice-Hall.

[4] Chang H, C. N., Miao M (2007). "Testing the relationship between three-component organizational/occupational commitment and organizational occupational turnover intention using a non-recursive model."J. Vocal Behav70.

[5] B. Mannheim, Y. B. a. J. T. (1997). "“'Alternative Models for Antecedents and Outcomes of Work Centrality and Job Satisfaction of High-Tech Personnel," " Human RelationsVol. 50(No. 12):pp. 1537-1562.

[6] H. L., \& Perry, J. L. (1981). "“'An empirical assessment of organization commitment and organizational effectiveness"."AdministrativeScience Quarterly, 26, 1-13.

[7] JC, M. (1985)." The relative importance of intrinsic and extrinsic rewards as determinants of wok satisfaction. Social. Q."26: 365-385.

[8] Wong S, S. V., Tsang N (1999). "The impact of demographic factors on Hong Kong hotel semployees' choice of job-related motivators. Int. J. Contemp. Hosp. Manage."11: 230-241.

[9] Curtis CR, U. R., Severt DE (2009). "Employee motivation and organizational commitment: a comparison of tipped and no tipped restaurant employees."Int. J. Hosp. Tourism Adm.10: 253-269.

[10] Mahaney CR, L. A. (2006). "The effect of intrinsic and extrinsic rewards for developers on information systems project success."Proj. Manage37:42-54.

[11] EL, D. (1975)." Intrinsic motivation. London: Plennum Press.".

[12] CARE (2007). "Organizational Gap Analysis Guidelines: A Resource Guide for Advancing Gender Equity and Diversity within CARE. Available at the Organizational Diversity page of CARE Academy's Learning Resources section: http://www.careacademy.org/learningresources/orgdiv.asp."

[13] Blau, G. J. B., K. B. (1987). "Conceptualizing how job involvement and organizational commitment affect." Academy of Management Review, 12(2): 288-300.

[14] Lawler (1986). "Impact of motivation and job involvement on employee commitment."

[15] Reitz, H. J., \& Jewell, L. N. (1979)."Sex, locus of control, and job involvement a six-country investigation."Academy of Management Journal, 22(1): 72-88.

[16] Berman, E. M., Bowman, J. S., West, J. P., \& Wart, M. R. V (2010). "Motivation: Possible, Probable or Impossible?." Human Resource Management in Public Service: Paradoxes, Processes and Problems California: SAGE Publications, Inc: 180.

[17] Ekerman, G. (2006). "Job Enrichment and Staff Motivation."Human Resource Management. Cape Town: Maskew Miller.Longman (Pvt) Ltd: (pp. 183-191).

[18] J, K. (1998). "Satisfy them with more than money. Workforce."77(11): 40-43.

[19] www.motivationcenter.blogspot.com/2006/03/implicationsof-maslow-hierarchy-of.html (nd) www.abrahammaslow.com/m_motivation/Hierarchy_of_Needs.asp (nd) 